\title{
Reproductive biology of the introduced sailfin catfish Pterygoplichthys pardalis (Pisces: Loricariidae) in peninsular Malaysia
}

\author{
A. SAMAT 1 , F. M. YUSOFF 2 , A. ARSHAD 3 , M. A. GHAFFAR ${ }^{4,5}$, S. M. NOR ${ }^{1}$ \\ A. L. B. MAGALHAES ${ }^{6}$ AND S. K. DAS ${ }^{1,4}$ \\ ${ }^{1}$ School of Environmental and Natural Resource Sciences, Faculty of Science and Technology, Universiti Kebangsaan \\ Malaysia - 43650, Bangi, Malaysia \\ ${ }^{2}$ Department of Biology, Faculty of Science, Universiti Putra Malaysia - 43400, Serdang, Malaysia \\ ${ }^{3}$ Department of Aquaculture, Faculty of Agriculture, Universiti Putra Malaysia - 43400, Serdang, Malaysia \\ ${ }^{4}$ Marine Ecosystem Research Centre, Faculty of Science and Technology, Universiti Kebangsaan Malaysia \\ Bangi - 43600, Malaysia \\ ${ }^{5}$ Fisheries and Aquaculture Sciences, University of Malaysia Terengganu, 21030 Kuala Nerus, Terengganu, Malaysia \\ ${ }^{6}$ Programa de Pos-Graduacao em Zoologia de Vertebrados, Pontificia Universidade Catolica de Minas Gerais \\ Belo Horizonte, Brazil \\ e-mail:nature@ukm.edu.my
}

\section{ABSTRACT}

\begin{abstract}
Reproductive biology of the introduced sailfin cat fish Pterygoplichthys pardalis in the Langat River of peninsular Malaysia was studied. Fish samples were collected monthly from Langat River during March 2003 - June 2004. The sex ratio observed for $P$. pardalis was female-biased with 1: 2. Gonadal maturity stage is achieved at $12.5 \mathrm{~cm}$ standard length (SL) for males and $13.0 \mathrm{~cm} \mathrm{SL}$ for females. This species appeared to have continuous spawning that peaked when water levels were high between September and January. Egg sizes were found to reach as large as $3.3 \mathrm{~mm}$ in dia in the ovary; suggesting that they spawn in batches. Fecundity varied from 1297 to 18791 numbers per brood, proportional to individual size. Data obtained from this study indicate that the introduced sailfin cat fish has successfully colonised in Langat River in Malaysia.
\end{abstract}

Keywords: Introduced cat fish, Peninsular Malaysia, Pterygoplichthys pardalis, Reproduction

\section{Introduction}

Catfishes of the family Loricariidae are ecologically diverse and widely distributed within South America (Suzuki et al., 2000). Further from its native tropical region of South America, the sailfin catfish Pterygoplichthys pardalis has been reported in south-east Asia including peninsular Malaysia (Chavez et al., 2006; Page and Robin, 2006; Samat et al., 2008). One specimen was recently recorded in Siberia (Simonovic et al., 2010). According to Agostinho et al. (1995) fishes of this family are able to tolerate a wide range of habitat conditions because of diversity in reproductive strategies. Their successful establishment in new habitats beyond native regions are also attributed to absence of natural predators and no human exploitation (Rueda-Jasso et al., 2013).

Reproduction in fishes can be easily affected by environmental variables such as temperature and water flow regimes (Devine et al., 2000; Chellappa et al., 2003; Schaan et al., 2009). In temperate waters, daily development generally increases with increasing temperature (Pepin, 1991; Dorts et al., 2012), but for tropical waters, several other environmental variables such as availability of food and crowding might also affect life history parameters (Lowe-McConnell, 1987; Tedesco and Hugueny, 2006).

Studies on reproduction evaluates size at maturity, sex ratio, gonadosomatic index (GSI), egg size and fecundity, and permit quantification of the reproductive capacity while providing some insight into a population's reproductive potential (Paugy, 2002; Venturelli et al., 2010). Although peninsular Malaysia has considerable numbers of oviparous non-native fishes $(n=22)$, there is no information available about their reproductive biology (Chong et al., 2010). Studies that consider the reproduction of oviparous fish outside their natural range provide the parameters for understanding their establishment in invaded ecosystems. Thus our aim in this study was to examine the reproductive biology of the non-native sailfin catfish $P$. pardalis in Langat River, Malaysia.

\section{Material and methods}

The study was conducted at Langat River that is located in the west coast of peninsular Malaysia (Fig. 1). Climate in the region is humid with mean annual temperatures 


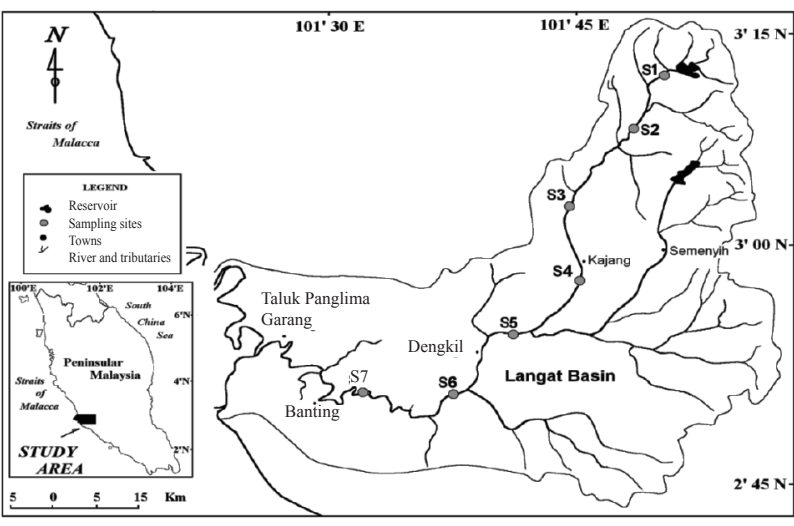

Fig. 1. Map showing Langat River and the sampling sites S1 to S7

varying between 25 and $32^{\circ} \mathrm{C}$. Two seasons prevail namely, the south-west monsoon with winds blowing from May to September, and the north-east monsoon that generally occurs from November to February. March and October are the transition months between the monsoons. Monthly rainfall in the study area during these two monsoon seasons ranges from 180 to $330 \mathrm{~mm}$.

Wet and dry seasons were indicated by mean monthly water level measured to the nearest $0.1 \mathrm{~m}$ using a data logger (HOBO-Model-U20-001-01) placed in the river at Site-6. Fish samples were collected monthly from the main Langat River, for 16 months from March 2003 to June 2004, using cast nets thrown within the area between the shoreline and the middle part of the river. Standard length (SL) and weight (W) of each individual fish caught were measured to the nearest $0.1 \mathrm{~cm}$ and $0.1 \mathrm{~g}$, respectively.

The abdomen of each sample was dissected to expose the genital organs and male and female samples were identified based on macroscopic observation of gonad. Temporal variations in sex ratio were also determined to observe the occurrence of productive and non-productive periods. To determine the sex ratio variations for different individual size (SL) and categories (or size structure), a frequency distribution of the SL was constructed with $3 \mathrm{~cm}$ class intervals.

The gonadosomatic index (GSI) used for determining the reproductive status or phenology of a fish species (Mazzoni and Caramaschi, 1995; Chellappa et al., 2003) was calculated as a ratio of weight of gonad to the weight of the individual fish. GSI was calculated using the formula: $\mathrm{GSI}=100 \times(\mathrm{W} / \mathrm{W})$ (Solomon and Ramnarine, 2007; Simon et al., 2009) where $\mathrm{W}_{\mathrm{g}}$ is weight of wet gonad $(\mathrm{g}), \mathrm{W}$ is total wet body weight without $\operatorname{gonad}(\mathrm{g})$.

The reproductive season of the fish was determined by examining the monthly dynamics of the GSI value based on gonad maturity stages as suggested by Kesteven (1960). Monthly values of the gonadosomatic index (GSI) were also plotted and analysed, together with temporal variation in sex ratios. The GSI values for both male and female individuals were represented in logarithmic scale in order to clearly show their temporal patterns.

The size at first maturation $\left(\mathrm{Lp}_{50}\right)$, was estimated according to the distribution of relative frequencies of the fishes by length classes (Martins and Haimovici, 2000; Liang et al., 2005). A frequency distribution of the SL was constructed at $3 \mathrm{~cm}$ intervals for fish with GSI values equal to or higher than 0.1 . The coefficient of determination $\left(\mathrm{r}^{2}\right)$ of the linear curves for both sexes was above $95 \%$.

Ovaries were excised from fresh samples of gravid females, weighed to the nearest $0.1 \mathrm{~g}$ and kept in Gilson's fluid (Bagenal, 1978). Fecundity was estimated from the ripe ova by a combination of gravimetric and volumetric methods (Lagler, 1978). After weighing the ovaries, small sub-samples from the anterior, middle and posterior portions of the ovary were removed, weighed and the eggs in the sub-samples were counted, averaged and extrapolated to the egg count of the entire ovaries using the formula: Fecundity $=$ Average number of eggs in subsample $\mathrm{x}$ Weight of ovary/Weight of subsample. The number and size of eggs were determined under a binocular dissecting microscope.

Eggs from the ovary subsamples were then sorted and counted in two size classes; Sc-1 clutch (larger than $2.0 \mathrm{~mm} \mathrm{dia}$ ) and the $\mathrm{Sc}-2$ clutch (smaller and equal to $2.0 \mathrm{~mm}$ in dia). The Sc-1 clutch of eggs, with full yolk and yellow in colour, were considered as eggs ready to be spawned. The remaining eggs (the Sc-2 clutch), which were whitish to pale yellow in colour were considered to be in the recruitment statge. Quantity of eggs for each clutch is presented as relative frequency $(\%)$. Any temporal change between these two clutches of eggs was evaluated according to water levels. The pattern produced from this analysis was taken to suggest the spawning season for $P$. pardalis.

Relationship between fecundity and the selected reproductive parameters was described as: $F=a X^{b}$ where $F$ is fecundity, $X$ is standard length $(\mathrm{cm}) /$ weight $(\mathrm{g}) /$ gonad weight $(\mathrm{g}) /$ water level $(\mathrm{m}), a$ is intercept and $b$ is the slope. The software, Origin (version 6.0) was employed to determine the relationship between fecundity and standard length, weight and gonad weight (Simon et al., 2012).

To study sex ratios, $\chi^{2}$ - test (goodness of fit) was used to determine whether the sex ratio differed from the expected ratio of $1: 1$. Size structure of the fish population assessed by length frequency distribution in size classes with numerical fish abundance and was also compared 
by $\chi^{2}$ test for each class. Relationships among the fishes, fecundity and egg size and water level were examined by means of correlation coefficient using Pearson correlation.

\section{Results}

The overall male to female ratio over the period of sixteen months for $P$. pardalis population in Langat River was $1: 1.7\left(\chi^{2}=28.01 ; \mathrm{p}<0.05\right)$, indicating that the sex ratio for this species was female biased. Size of male $P$. pardalis individuals during the study were between 16.0 and $38.0 \mathrm{~cm} \mathrm{SL}$ and of females between 10.8 and $36.0 \mathrm{~cm} \mathrm{SL}$. The SLs of both males and females were normally distributed according to size classes (Fig. 2). Statistically, the sex ratio departed from 1:1 ratio for fishes measuring between 21 and $33 \mathrm{~cm}$ in SL, a size range where females outnumbered males (Table 1).

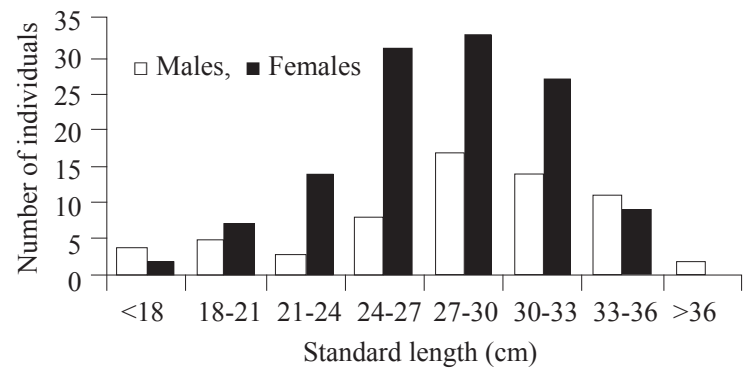

Fig. 2. Distribution in size classes of Pterygoplichthys pardalis of different sexes in Langat River

Table 1. Chi-square $(\chi 2)$ test for Pterygoplichthys pardalis sex ratio comparisons by size class in Langat River, $(\mathrm{F}=$ expected frequency)

\begin{tabular}{llllll}
\hline Size class $(\mathrm{cm})$ & Males & Females & Total & $\mathrm{F}$ & $\chi^{2}$ \\
\hline$<18$ & 4 & 2 & 6 & 3.0 & 0.67 \\
$18-21$ & 5 & 7 & 12 & 6.0 & 0.33 \\
$21-24$ & 3 & 14 & 17 & 8.5 & $7.12^{*}$ \\
$24-27$ & 8 & 31 & 39 & 19.5 & $13.56^{*}$ \\
$27-30$ & 17 & 33 & 50 & 25.0 & $5.12^{*}$ \\
$30-33$ & 14 & 27 & 41 & 20.5 & $4.12^{*}$ \\
$33-36$ & 11 & 9 & 20 & 10.0 & 0.20 \\
$>36$ & 2 & 0 & 2 & 1.0 & 2.00 \\
\hline$* \mathrm{p}<0.05$ & & & & &
\end{tabular}

Relatively higher GSI values for both male and female individuals of this species were detected from August to October 2003, which coincided with period of high water level in Langat River (Fig. 3). The study indicated that the number of $P$. pardalis in the gravid condition was more frequently found during wet season than dry season. In general, during wet season between August 2003 and January 2004 gravid females recorded for each month was more than $85 \%$. During dry season, percentage of gravid females for each month was less than $70 \%$.

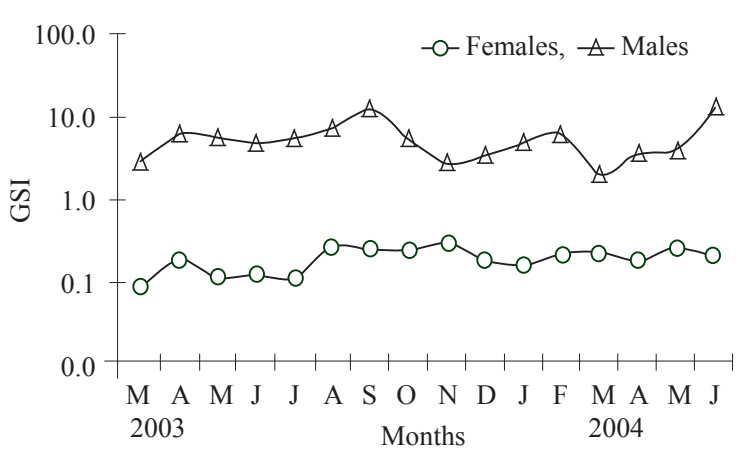

Fig. 3. Temporal variation of the gonadosomatic index (GSI for male and female Pterygoplichthys pardalis

In this study, the size at first maturity $\left(\mathrm{Lp}_{50}\right)$ was estimated to be at $12.5 \mathrm{~cm} \mathrm{SL}$ in males and $13 \mathrm{~cm} \mathrm{SL}$ in females (Fig. 4). Analysis revealed no difference in $\mathrm{LP}_{50}$ between males and females of $P$. pardalis $\left(\chi^{2}=0.010 ; p>0.05\right)$. Furthermore, the size of the fish measured did not correlate significantly with the gonad weight $\left(\mathrm{r}^{2}=0.0372 ; \mathrm{p}>0.05\right)$, suggesting year-round maturation.

The mean length, weight and fecundity of 225 gravid females of $P$. pardalis are presented in Table 2 . The mean body length of the fish ranged between $24.6 \pm 4.4$ and $30.8 \pm 3.3 \mathrm{~cm}$ (SL) and weight between $260.0 \pm 123.0$ and $552.9 \pm 132.7$ g. Ovary weights were recorded between 0.73 and $114.12 \mathrm{~g}$ and fecundity was

Table 2. Number of individuals, mean length, mean weight, and mean fecundity of Pterygoplichthys pardalis during the study period

\begin{tabular}{lllll}
\hline Month & $\mathrm{N}$ & $\mathrm{SL}(\mathrm{cm})$ & Weight $(\mathrm{g})$ & Fecundity \\
\hline March 2003 & 6 & $29.0 \pm 2.6$ & $450.9 \pm 76.7$ & $4132 \pm 1162$ \\
April & 15 & $27.1 \pm 2.3$ & $369.3 \pm 87.2$ & $5154 \pm 1663$ \\
May & 11 & $25.4 \pm 3.8$ & $327.1 \pm 115.3$ & $4972 \pm 1786$ \\
June & 11 & $27.6 \pm 3.4$ & $404.6 \pm 130.0$ & $5637 \pm 2821$ \\
July & 13 & $28.6 \pm 2.0$ & $428.2 \pm 81.7$ & $6718 \pm 1881$ \\
August & 15 & $29.9 \pm 4.3$ & $492.8 \pm 187.4$ & $8526 \pm 3296$ \\
September & 22 & $26.6 \pm 4.2$ & $361.0 \pm 136.9$ & $7081 \pm 2961$ \\
October & 10 & $30.8 \pm 3.3$ & $552.9 \pm 132.7$ & $11480 \pm 2458$ \\
November & 24 & $30.5 \pm 4.0$ & $472.7 \pm 142.6$ & $9395 \pm 3767$ \\
December & 23 & $30.3 \pm 3.1$ & $448.5 \pm 110.9$ & $6301 \pm 3492$ \\
January 2004 & 19 & $24.6 \pm 4.4$ & $260.0 \pm 123.0$ & $7129 \pm 2566$ \\
February & 12 & $27.9 \pm 4.6$ & $406.5 \pm 177.6$ & $8273 \pm 3839$ \\
March & 8 & $29.5 \pm 2.0$ & $422.8 \pm 73.0$ & $10428 \pm 4061$ \\
April & 13 & $29.7 \pm 3.8$ & $386.1 \pm 29.6$ & $9698 \pm 4247$ \\
May & 10 & $26.9 \pm 4.2$ & $324.5 \pm 143.3$ & $7659 \pm 3530$ \\
June & 13 & $29.0 \pm 6.3$ & $476.6 \pm 213.2$ & $8918 \pm 3256$
\end{tabular}

between 1,297 and 18,791 with monthly averages higher than 4,000 nos. of ripe egg. The egg size in Sc-1 group was found to be as large as $3.3 \mathrm{~mm}$ in dia, with full yolk and distinguished by its bright yellowish colour. Eggs in Sc-2 group were smaller than $2 \mathrm{~mm}$ in dia and appeared cream to whitish in colour. 


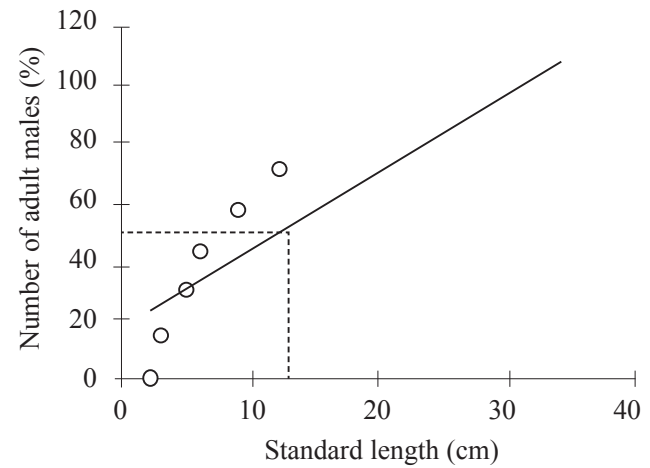

(a)

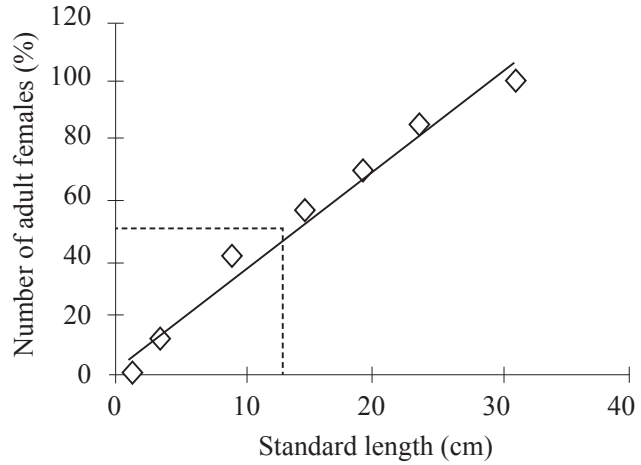

(b)

Fig. 4. Size at first gonadal maturation based on length frequency distribution of adult Pterygoplichthys pardalis in Langat River (a) male; (b) female

A larger number of ripe eggs (Sc-1) were observed in the ovary during the period of low water level than during the period of high water levels (Fig. 5). This suggests the likelihood that the species keep their ripe eggs at low water levels and later release them when water levels are high. This finding that the GSI value of this fish is influenced by high and low water levels is consistent with the findings of other researchers (Goulding, 1981; Lowe-McConnell, 1987).

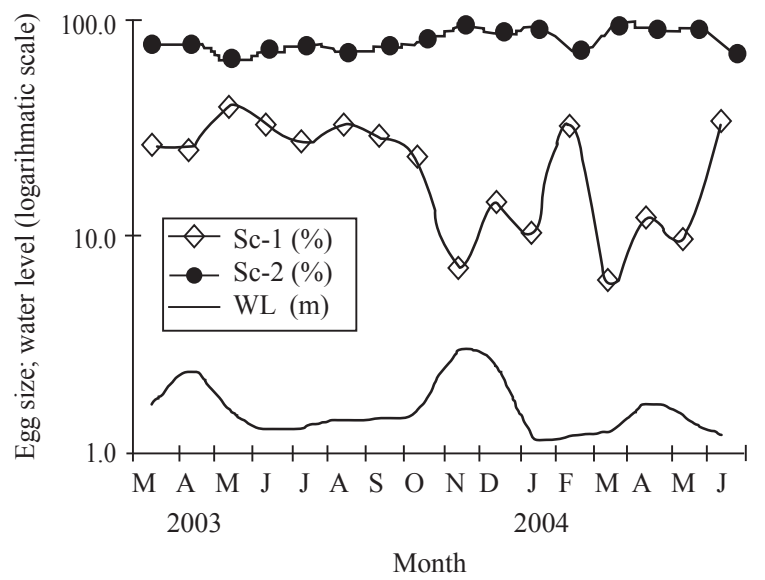

Fig. 5. Temporal pattern of frequency distribution of eggs (Sc-1 and Sc-2) of Pterygoplichthys pardalis and water level (reflecting rainfall) over the period of 16 months

Fecundity of $P$. pardalis from Langat River was positively correlated with body size and weight, as well as with gonad weight. However, a negative relationship was found between fecundity and water level. This could be due to the release of ripe eggs ( $\mathrm{Sc}-1$ ), while the developing eggs (Sc-2) were left behind in the ovary during high water level period.

\section{Discussion}

Female $P$. pardalis in the Langat River were found to outnumber males throughout the year. Similar trend was also reported for other Loricariids such as Liposarcus multiradiatus; an introduced armored catfish in Taiwan (Liang et al., 2005). However, Mazzoni and Caramaschi (1995) estimated the overall sex ratio for two species of armored catfish Hypostomus affinis and H. luetkeni (Family: Loricariidae) in their native habitat as 1:1.

The smaller number of male fish recorded at high water levels might be due to lesser chances of the fish being caught since at high water levels the males may have still been guarding their nest while the females were living free in the open water. This is in line with the findings of Mazzoni et al. (2002), Power (2003) and Liang et al. (2005) that the males are responsible for the protection of eggs and juveniles.

Relatively, more male than female individuals were recorded for fish smaller than $18 \mathrm{~cm} \mathrm{SL}$. Sex of fish may change at their first maturity $\left(\mathrm{Lp}_{50}\right)$, as it is common for fishes (Allsop and West, 2003; Gardner et al., 2005). If this is the case for P. pardalis of Langat River, the sex ratio would be balanced, as has been estimated for its congeners (Mazzoni and Caramaschi, 1995). Males outnumbering females was also found for $P$. pardalis individuals larger than $330 \mathrm{~mm}$. At this size it has been suggested that female mortality may be higher than male mortality due to the females' greater reproductive investment (Liang et al., 2005).

Fish can become sexually mature at various ages, depending on the species. For most fishes, reproduction starts when they have reached about half of their likely maximum size. Our estimated $\mathrm{Lp}_{50}$ values for $P$. pardalis are comparable with those estimated for Hypostomus affinis and Hypostomus luetkeni at $14.4 \mathrm{~cm} \mathrm{SL}$ and $16.0 \mathrm{~cm} \mathrm{SL}$, respectively (Mazzoni and Caramaschi, 1995). However, the estimated $\mathrm{Lp}_{50}$ values for P. pardalis were much lower than that of its congeneric Pterygoplichthys 
multiradiatus, which has $\mathrm{Lp}_{50}$ value at $25.0 \mathrm{~cm} \mathrm{SL}$ (Liang et al., 2005).

Liang et al. (2005) suggested that Liposarcus multiradiatus in Taiwan invested more energy for environmental adaptation rather than for reproduction unlike $H$. affinis and H. luetkeni in Brazil (Mazzoni and Caramaschi, 1995, 1997). Our findings agree to an extent with Mazzoni and Caramaschi $(1995,1997)$ as Malaysia and Brazil are in the tropical climate realm, while Taiwan is subtropical. Differences in climatic conditions may potentially interfere with or delay the species' reproductive processes including the onset of sexual maturity.

Generally, change in water temperature affects the reproduction of a fish (Yoneda and Wright, 2005; Pankhurst and Munday, 2011). Therefore, a habitat with a stable water temperature (e.g., tropical rivers) is expected to be a better place for fish to reproduce than habitats with fluctuating water temperature (e.g., subtropical rivers). When water temperature fluctuates, fishes spawn only when the temperature remains within the specific range conducive for spawning of the species and hence fluctuating temperatures would limit the length of the spawning period and thus the reproductive rate of the fish. Temperature may not be an important limiting factor for spawning of fish that live in a habitat with stable or less fluctuating water temperature.

It may be presumed that decreasing water temperature during high water levels trigger the spawning mechanism of this species. Such a phenomenon is a common reproductive strategy in most tropical and neotropical fishes (Merigoux et al., 1999; Ferreira, 2000). In addition, food is always much more abundant, and space more available during wet season which enhance fish population growth (Goulding, 1981; De-Merona and De-Merona, 2004).

Spawning in batches has also been reported for other $P$. pardalis congeners such as Loricariichthys platymetopon, Loricariichthys sp. and Loricaria sp. (Suzuki et al., 2000), and Hypostomus affinis (Duarte and Araujo, 2002). In the mature ovaries of a batch spawner like $P$. pardalis, mature eggs with size $>2.0 \mathrm{~mm}$ (Sc-1) are found together with immature ones with size less than $0.5 \mathrm{~mm}$ in dia known as pre-vitellogenic eggs ( $\mathrm{Sc}-2)$. This Sc-2 group of eggs is expected to remain in the ovaries after the first spawning, and, together with those in the primary growth, form the egg stock for the next spawning season. Only a single cohort of Sc-1 is recruited and spawned during a specific spawning period. However, not all Loricariid fishes spawn in batches. Suzuki et al. (2000) have reported that several others such as Hypostomus ternetzi, Megalancistrus aculeatus and Rhinelepis aspera are total spawners.

The way the armored catfishes fertilise their eggs differs across species For Hoplosternum littorale (Callichthyids), there are indications that female drink the sperms and the fertilisation takes place after the sperms have passed through the digestive tract (Hostache and Mol, 1998). On the other hand, loricariids have external fertilisation and development (Suzuki et al., 2000), and thus egg characters are important especially in terms of their resistance to the environmental conditions where fertilisation takes place. According to Dorucu et al. (2001), egg size may affect fecundity, embryo survival rate and fry size. Naturally, egg size of each species of fish is strongly related to internal (i.e., genetic) factors and may be influenced by environmental conditions or both (Kaeriyama et al., 1995).

The number of eggs per brood of $P$. pardalis in the Langat River was higher than other loricariids of its native habitat of South America such as Hypostomus affinis with 2,350 (Mazzoni and Carasmachi, 1995), H. ternetzi with 2,800 and Plecostomus ancistroides with 970 eggs. However, it is far lower than the eggs per brood of Rhinelepis aspera with 47,370 eggs (Suzuki et al., 2000). Positive relationships between fecundity in an individual species and its size, body weight and gonad weight found in this study are common for fish in general (Bagenal, 1978), including loricariids (Mazzoni and Caramaschi, 1995; Duarte and Aroujo, 2002).

Among freshwater species, it is usually observed that hatching success is low in unprotected eggs than in species which exhibit parental care (Dahlberg, 1979). Moodie and Power (1982), Suzuki et al. (2000), and Hoover et al. (2004) described at least three reproductive strategies of loricariids during early stages of their life cycle viz., no parental care (e.g., Rhinelepis aspera), external bearers (e.g., Loricaria and Loricariichthys), and guarders (e.g., Hypostomus, Liposarcus and Pterygoplichthys).

This study has described several key aspects of the reproductive biology of sailfin catfish $P$. pardalis in Malaysian waters. It is clear that $P$. pardalis has made its way in Malaysian waters to propagate, survive and finally become an important component in the local fish community. The overall environmental condition of Langat River facilitates the reproductive activities of this introduced sailfin catfish, thus making it a successful invader. 


\section{Acknowledgements}

This study was financed by the research grant UKM-ST-08-FRGS0240-2010 awarded to the first author by Ministry of Science, Technology and Innovation, Malaysia.

\section{References}

Agostinho, A. A., Matsuura, Y., Okada, E. K. and Nakatani, K. 1995. The catfish, Rhinelepis aspera (Teleostei; Loricariidae), in the Gua1'ra region of the Parana' River: an example of population estimation from catch-effort and tagging data when migration and immigration are high. Fish. Res., 23: 333-344.

Allsop, D. J. and West, S. A. 2003. Constant relative age and size at sex change for sequentially hermaphroditic fish. J. Evol. Biol., 16: 921-929.

Bagenal, T. 1978. Methods for assessment of fish production in freshwaters. Blackwell Scientific, Oxford, London, 365 pp.

Chavez, J. M., De-La-Paz, R. M., Manohar, S. K., Pagulayan, R. C. and Carandang-VI, J. R. 2006. New Philippine record of south American sailfin catfishes (Pices: Loricariidae). Zootaxa, 1109: 57-68.

Chellappa, S., Camara, M. R., Chellappa, N.T., Beveridge, M.C.M. and Huntingford, F. A. 2003. Reproductive ecology of a neotropical cichlid fish, Cichla monoculus (Osteichthyes: Cichlidae). Braz. J. Biol., 63(1): 17-26.

Chong, V. C, Lee, P. K. Y. and Lau, C. M. 2010. Diversity, extinction risk and conservation of Malaysian fishes. J. Fish Biol., 76: 2009-2066.

Dahlberg, M. D. 1979. A review of survival rates of eggs and larvae in relation to impact assessments. Mar. Fish. Rev., 41(3): $1-12$

De-Merona, B. and Rankin-de-Merona, J. 2004. Food resource partitioning in a fish community of the central Amazon floodplain. Neotrop. Ichthyol., 2(2): 75-84.

Devine, J. A., Adams, C. E. and Maitland, P. S. 2000. Changes in reproductive strategy in the ruffe during a period of establishment in a new habitat. J. Fish Biol., 56: 1488-1496.

Dorts, J., Grenouillet, G., Douxfils, J., Mandiki, S. N. M., Milla, S., Silvestre, F. and Kestemont, P. P. 2012. Evidence that elevated water temperature affects the reproductive physiology of the European bullhead Cottus gobio. Fish Physiol. Biochem., 38: 389-399.

Dorucu, M., Yazlak, H. and Ozturk, E. 2001. The variation in fecundity and egg size of cultured rainbow trout, (Oncorhynchus mykiss, W. 1792). FU Fen ve Muh Bilimleri Dergisi, 13(2): 269-274.

Duarte, S. and Araujo, F. G. 2002. Fecundity of the Hypostomus affinis (Siluriformes, Loricariidae) in the Lajes Reservoir, Rio de Janeiro, Brazil. Rev. Biol. Trop., 50(1): 193-197.
Ferreira, L. V. 2000. Effects of flooding duration on species richness, floristic composition and forest structure in river margin habitat in Amazonian blackwater floodplain forests: implications for future design of protected areas. Biol. Conserv., 9: 1-14.

Gardner, A., Allsop, D. J., Charnov, E. L. and West, S. A. 2005. A dimensionless invariant for relative size at sex change in animals: Explanation and implication. American Naturalist, 165(5): 551-566.

Goulding, M. 1981. The fishes and the forest: exploration in Amazonian natural history. University California Press, Calif, $280 \mathrm{pp}$

Hoover, J. J., Killgore, K. J. and Cofrancesco, A. F. 2004. Suckermouth catfishes: threats to aquatic ecosystems of the United States? ANSRP Bull., 4(1): 1-9.

Hostache, G. and Mol, J. H. 1998. Reproductive biology of the neotropical armoured catfish Hoplosternum littorale (Siluriformes-Callichthyidae): a synthesis stressing the role of the floating bubble nest. Aquat. Living Res., 1(3): 173-185.

Kaeriyama, M., Urawa, S. and Fukuwaka, M. 1995. Variation in body size, fecundity and egg size of Sockeye and Kokanee salmon, Oncorhynchus nerka, released from hatchery. Sci. Rep. Hokaido Sal. Hatch., 49: 1-9.

Kesteven, G. L. 1960. Manual of field methods in fishery biology FAO Manual in Fish Science. FAO. Rome, 152 pp.

Lagler, K. F. 1978. Capture, sampling and examination of fishes. In: Bagenal, T. B. (Eds.), Methods of assessment of fish production in freshwater. Blackwell Scientific, Oxford, $7-47 \mathrm{pp}$.

Liang, S. H., Wu, H. P. and Shieh, B. S. 2005. Size structure, reproductive phenology and sex ratio of an exotic armored catfish (Liposarcus multiradiatus) in the Kaoping River of Southern Taiwan. Zool. Stud., 44(2): 252-259.

Lowe-McConnell R. H. 1987. Ecological studies in tropical fish communities. Cambridge University Press, Cambridge, $382 \mathrm{pp}$.

Martins, A. S. and Haimovici, M. 2000. Reproductive biology of the cutlassfish Trichiurus lepturus in the southern Brazil subtropical convergence ecosystem. Scientia Marina, 64(1): 97-105.

Mazzoni, R. and Caramaschi, E. P. 1995. Size structure, sex ratio and onset of sexual maturity of two species of Hypostomus. J. Fish Biol., 47: 841-849.

Mazzoni, R. and Caramaschi E. P. 1997. Observations on the reproductive biology of female Hypostomus luetkeni Lacepede 1803. Ecol. Freshw. Fish., 6: 53-56.

Mazzoni, R., Caramaschi, E. P. and Fenerich-Verani, N. 2002. Reproductive biology of a characidiinae (Osteichthyes, Characidae) from the Ubatiba River, Marica-RJ. Braz. J. Biol., 62(3): 487-494. 
Merigoux, S., Huguency, B., Ponton, D., Statzner, B. and Vauchel, P. 1999. Predicting diversity of juvenile neotropical fish communities: patch dynamics versus habitat state in floodplain creeks. Oecologia, 118: 503-516.

Moodie, G. E. and Power, M. E. 1982. The reproductive biology of an armoured catfish, Loricaria urucantha, from Central America. Environ. Biol. Fish., 7(2): 143-148.

Page, L. M. and Robin, R. H. 2006. Identification of sailfin catfishes (Teleostei: Loricariidae) in southeastern Asia. Raffles B. Zool., 54(2): 455-457.

Pankhurst, N. W. and Munday, P. L. 2011. Effects of climate change on fish reproduction and early life history stages. Mar. Freshwat. Res., 62(9): 1015-1026.

Paugy, D. 2002. Reproductive strategies of fishes in a tropical temporary stream of the Upper Senegal basin: Baoule River in Mali. Aquat. Liv. Resour., 15: 25-35.

Pepin, P. 1991. Effect of temperature and size on development, mortality, and survival rates of the pelagic early life history stages of marine fish. Can. J. Fish. Aquat. Sci., 48(3): 503-518

Power, M. E. 2003. Life cycles, limiting factors, and behavioural ecology of four loricariid catfishes in a Panamian River. In: Arratia, G., Kapoor, B. G., Chardon, M. and Dlogo, R. (Eds.), Catfishes. Science Publishers, Inc., Enfield, NH.

Rueda-Jasso, R. A., Campos-Mendoza, A., Arreguin-Sanchez, F., Diaz-Pardo, E. and Martinez-Palacios, C. A. 2013. The biological and reproductive parameters of the invasive armored catfish Pterygoplichthys disjunctivus from Adolfo Lopez Mateos El Infiernillo Reservoir, MichoacanGuerrero, Mexico. Revista Mexicana de Biodiversidad, 84: 318-326.

Samat, A., Shukur, M. N., Mazlan, A. G., Arshad, A. and Fatimah, M. Y. 2008. Length-weight relationship and condition factor of Pterygoplichlthys pardalis (Pisces: Loricaridae) in Malaysian Peninsula. Res. J. Fish. Hydorbiol., $3(2): 48-53$

Schaan, A. B., Giora, J. and Fialho, C. B. 2009. Reproductive biology of the Neotropical electric fish Brachyhypopomus draco (Teleostei: Hypopomidae) from southern Brazil. Neotrop. Ichthyol., 7(4): 737-744.

Simon, K. D., Bakar, Y., Samat, A., Zaidi, C. C., Aziz, A. and Mazlan. A. G. 2009. Population growth, trophic level, and reproductive biology of two congeneric archerfishes (Toxotes chatareus, Hamilton 1822 and Toxotes jaculatrix, Pallas 1767) inhabiting Malaysian coastal waters. J. Zhejiang Univ. Sci. B., 10(12): 902-911.

Simon, K. D., Bakar, Y., Mazlan, A. G., Zaidi, C. C., Samat, A., Arshad, A., Temple, S. E. and Brown-Peterson, N. J. 2012. Aspects of the reproductive biology of two archerfishes Toxotes chatareus, (Hamilton 1822) and Toxotes jaculatrix (Pallas 1767). Environ. Biol. Fish., 93: 491-503.

Simonovic, P., Nikolic, V. and Grujic, S. 2010. Amazon sailfin catfish Pterygoplichthys pardalis (Castellnau, 1855) (Loricariidae, siluriformes), a new fish species recorded in the Serbian section of the Danube River. Biotechnol. Biotechnological Equip., 24(2): 655-660.

Solomon, F. N. and Ramnarine, I. W. 2007. Reproductive biology of white mullet, Mugil curema (Valenciennes) in the Southern Caribbean. Fish. Res., 88: 133-138.

Suzuki, H. I., Agostinho, A. A. and Winemiller, K. O. 2000. Relationship between oocyte morphology and reproductive strategy in loricariid catfishes of the Parana River, Braz. J. Fish Biol., 57: 791-807.

Tedesco, P. and Hugueny, B. 2006. Life history strategies affect climate based spatial synchrony in population dynamics of West African freshwater fishes. Oikos, 115: 117-127.

Venturelli, P. A., Murphy, C. A., Shuter, B. J., Johnston, T. A., Van Coeverden De Groot P. J., Boag, P. T., Casselman, J. M., Montgomerie, R., Wiegand, M. D. and Leggett, W. C. 2010. Maternal influences on population dynamics: evidence from an exploited freshwater fish. Ecol., 91(7): 2003-2012.

Yoneda, M. and Wright, P. J. 2005. Effect of temperature and food availability on reproductive investment of first-time spawning male Atlantic cod, Gadus morhua. ICES J. Mar. Sci., 62(7): 1387-1393. 